\title{
POLITIK PENDIDIKAN AGAMA DAN PERUBAHAN PRILAKU DI SUMATERA BARAT
}

\author{
Delmus Puneri Salim dan Lies Kryati \\ Institut Agama Islam Negeri Manado \\ Jl. Manguni, Malendeng, Tikala, Kota Manado, Sulawesi Utara
}

\begin{abstract}
This paper demonstrates how the Islamic education has been used to reflect social problems in the region. The paper argues that decadency and the use of drugs and other social problems has enabled the regional governments to engage in Islamic education. The paper suggests that the involvement was driven by the capacity to reduce fears of social problems in the society. It also argues that the other mechanism to solve social problems are overlooked as the paper presents availability of jobs concerning at customers' satisfaction would overcome social problems.
\end{abstract}

Keywords: Islamic education, Politics, Social Problems.

\section{PENDAHULUAN}

Sumatera Barat adalah salah satu provinsi dengan mayoritas penganut agama Islam di Indonesia. Secara administratif, Sumatera Barat terdiri dari 19 Kabupaten dan Kotamadya dengan jumlah penduduk mendekati lima juta jiwa (BPS 2011). Budaya dominan adalah budaya Minangkabau yang terkenal dengan matrilinealnya dimana tanah dan rumah yang diwarisi turun temurun dari ibu kepada anak perempuannya dan anak laki-laki mewarisi kesukuan dari ibunya juga. Suku Minangkabau juga terkenal dengan budaya merantau yang mendorong terciptanya budaya terbukaterhadap dinamika ide-ide dari luar daerah. Secara geografis, Sumatera Barat didominasi gunung dan bukit barisan yang menunjukkan pusat budaya daerahnya yang bersumber dari dalam dan daerah pesisir yang memudahkan perkembangan budaya dari luar. Sudah terjadi dalam sejarah yang panjang Minangkabau perkawinan antara pedagang dan pengunjung ke daerah ini yang melewati system perdagangan dari India and Malaka dimana emas dan kopi dulu menjadi bahan perdagangan utama antara abad ke empat dan Sembilan belas (Summerfield and Summerfield 1999: 31). Jalur perdagangan ini mempunyai peran yang sangat penting dalam masuknya Islam sufi/tarekat pada abad ke enam belas sampai abad ke delapan belas (Dobbin 1983), dari masa inilah Islam mulai menjadi penting dalam identitas budaya Minangkabau.

Hubungan antara budaya Minangkabau dan Islam telah ditandai dengan hubungan baik yang kooperatif maupun yang konflik. Hubungan kooperatif dimulai dengan berdirinya masjid di setiap nagari di daerah ini mulai pada abad ke tujuh belas. Konflik muncul ketika pandangan keagamaan mulai merubah prinsip-prinsip matrilineal dan heterodoksi Islam sufi/tarekat pada awal abad ke Sembilan belas. Ketika colonial Belanda membantu prinsip-prinsip adat dalam konflik tersebut, secara paradok, Islam malah menjadi bagian yang penting dalam identitas Minangkabau. 
Sejak saat itu, Islam mulai menjadi elemen penting dalam identitas daerah Sumatera Barat dan meningkat kembali sejak zaman reformasi.

\section{METODE PENELITIAN}

Paper ini mencoba untuk menggunakan pendekatan politik dalam rangka untuk memberikan gambaran yanglebih komprehensif tentang perkembangan pendidikan agama dan perubahan prilaku di Sumatera Barat. Untuk itu, makalah ini didasarkan pada metodologi yang berhubungan dengan disiplin politik, dan bahasa dalam pendekatan yang lebih dekat dengan kategori politik kualitatif. Penelitian ini dilakukan di Sumatera Barat karena Sumatera Barat memiliki populasi mayoritas Islam dan telah mengimplementasikan regulasi tentang Islam lebih banyak dari daerah lain di Indonesia. Dengan memiliki jumlah penduduk sebesar 4,5 juta (BPS 2011).

Analisa dokumen dilakukan pada umumnya selama tiga tahun dari muatan berita lokal (2008-2010), yang memberikan gambaran baik presentasi Islam publik sebagai motivator kebijakan politik oleh politisi dan bagaimana tokoh masyarakat memanfaatkan pendidikan agama Islam dalam proses politik tersebut. Teks-teks dokumen tersebut dianalisa dalam rangka menunjukkan kontruksi politik, sosial dan agama yang dibuat ketika memunculkan dan memvalidasi peraturan-peraturan bernuansa Islam, dengan tujuan memahami cara-cara publik figure menggunakan bahasa agama untuk menjaga identitas Islam Minangkabau dan dalam waktu yang sama identitas minangkabau digerakkan untuk menjustifikasi penggunaan Islam sebagai argumen untuk mengenalkan kontrol sosial dalam bentuk-bentuk baru.

Analisa dilakukan dengan menggunakan tehnik yang berkaitan dengan kritik discourse analisis yang ingin menghasilkan pandangan bahwa wacana menghasilkan kembali atau melawan ketidak adilan sosial dan politik, penyalahgunaan kekuasaan dan dominasi politik (Fairclough, 1995). Analisa empati, penggunaan kalimat methapor, dan pemilihan kata-kata tertentu, semua menunjukkan usaha publik figur untuk memposisikan diri mereka dalam praktek-praktek Islam di Sumatera Barat dan atau perlawanan terhadap proses tersebut. Teknik over-wording dan dan identifikasi eksperimen, ekspressif dan rasional value digunakan untuk mengkategorikan tema, ide, pandangan dan peran yang penting untuk memahami perjuanganideologi, opini, pemahaman, dan hubungan timbal balik (Fairclough, 1989: 112-115). Semua teknik ini digunakan untuk memahami klaim Islam sebagai justifikasi perkembangan pendidikan agama Islam di Sumatera Barat.

\section{HASIL PENELITIAN DAN PEMBAHASAN}

\section{Agama dan Politik di Sumatera Barat}

Hubungan agama dan politik adakalanya saling bertentangan, berjalan sendiri-sendiri dan bekerjasama satu sama lain. Varian pemikiran agama dan politik sering dianggap berseberangan, misalnya, dalam menentukan kriteria pemimpin dan siapa yang berhak memilih pemimpin. Kaum agamawan sering merekomendasikan nilai-nilai agama sebagai kriteria utama dalam menentukan pemimpin politik sementara politik bisa memberikan 
peluang kepada siapa saja warga negara yang memenuhi syarat untuk mencalonkan diri dengan dukungan partai politik atau orang dengan jumlah tertentu. Begitu juga dengan kriteria siapa saja yang termasuk dalam menentukan pemimpin politik tersebut. Hampir tidak ada satupun institusi agama yang memberikan hak kepada semua jamaahnya untuk terlibat dalam pemilihan pemimpin agama. Pemilihan imam di beberapa masjid sudah mulai melibatkan sebagian jamaah tetapi pemilihan pimpinan lembaga dan organisasi keagamaan sering dilakukan hanya oleh kelompok kecil yang biasa disebut tim formatur. Sementara dalam system politik saat ini, system one man one vote yang digunakan. Ini menunjukkan bahwa suara pemimpin agama dianggap sama dengan suara mereka yang diklaim berdosa oleh para pemimpin agama tersebut.

Agama dan politik juga bisa berjalan masing-masing tanpa mengganggu yang lain. Misalnya, pemerintah daerah memprioritaskan pembangunan kawasan pelabuhan untuk memicu pertumbuhan perekonomian daerah. Anggaran negara yang digunakan oleh pemerintah daerah tersebut sangat jarang mendapat kritikan atau masukan dari tokohtokoh agama, sama seperti, pemerintah daerah yang jarang terdengar mengkritisi penggunaan anggaran lembaga dan organisasi agama nonpemerintah yang bersumber dari umatnya masing-masing.

Namun demikian, hubungan agama dan politik lebih banyak saling bekerjasama di daerah ini sama seperti daerah-daerah lain di Indonesia. Sejak kemerdekaan, agama sudah mempengaruhi sisi kebijakan politik dan pembangunan di Sumatera Barat. Para pengambil kebijakan telah mendirikan dan mensupport berbagai macam institusi dan lembaga agama, baik secara utuh, seperti kementerian agama wilayah,maupun secara semi, seperti MUI dan Muhammadiyah yang sering menerima bantuan dari pemerintah. Pemerintah daerah juga telah mengambil kebijakan untuk membantu membiayai pembangunan banyak rumah ibadah dan honorarium para pemimpin agama setiap tahun. Pemerintah daerah kabupaten dan kotamadya juga telah menyelenggarakan dan melibatkan tokoh-tokoh agama dan lembaga agama dalam kegiatan-kegiatan seremonial keagamaan yang beragam setiap tahun dari anggaran keuangan negara.

Sebaliknya, tokoh-tokoh agama dan lembaga agama sudah lama mempengaruhi pemerintahan di Sumatera Barat. Banyak tokoh-tokoh agama terlibat langsung dalam mengambil kebijakan politik dengan menjadi anggota legislative, eksekutif dan yudikatif. Begitu juga, rekomendasi-rekomendasi tokohtokoh dan lembaga agama terhadap calon pemimpin daerah selalu terdengar setiap kali ada pemilihan pemimpin di wilayah ini.

\section{Pendidikan Agama dan wacana publik di Sumatera Barat}

Dalam wacana publik di Sumatera Barat, pendidikan agama sangat dekat dikaitkan dengan tokoh-tokoh Minangkabau yang telah mengisi peran sebagai pemimpin nasional sebelum dan masa awal sesudah kemerdekaan. Dalam budaya Minangkabau, intelektualitas dipandang sebagai elemen penting dalam identitas budaya. Sebagai mana yang pernah 
disampaikan oleh Bapak Gamawan Fauzi “ Kita sering terjebak dalam sukses tokoh-tokoh Minangkabau pada masa lalu... kesuksesan mereka seharusnya bukanlah hal yang selalu dijadikan romantika sejarah. Dibandingkan dengan kondisi saat ini, hanya beberapa dari mereka yang bergelar master dan doctor. Sebagaian mereka juga belum pernah mengalami pendidikan di perguruan tinggi. Tetapi mereka telah membuktikan tanah Minangkabau adalah tanah yang penuh dengan industri otak (Padang Ekspres 28 January 2009)

Meskipun tokoh-tokoh Minangkabau dalam sejarah seperti Syahrir dan Hatta pernah mendalami pendidikan sekolah sekuler Belanda, pemimpin-pemimpin di Sumatera Barat sering menyebutkan bahwa ketokohan mereka bersumber hanya dari pendidikan agama Islam yang mereka ikuti. Menurut Muhammad Kosim, guru di SMP Negeri 8 Padang:

Pendidikan di sekolah umum pada masa lalu diisi dengan semangat pembelajaran di surau... sekarang masyarakat sangat merindukan lahirnya tokoh-tokoh sekaliber Hamka, Mohammad Hatta, Sutan Syahrir, M. Natsir, M. Yamin, Agus Salim dan yang lain (Padang Ekspres 14 May 2010).Bapak Kosim selanjutnya mengklaim bahwa kerinduan tersebut bisa terwujud karena otonomi daerah telah memberikan control kepada pemerintah daerah untuk mengelola pendidikan local: Dengan adanya Otonomi daerah dan kurikulum nasional 2006 berarti kita dapat mengembangkan program pendidikan daerah yang berkualitas. Di Sumatera Barat, budaya Minangkabau dan budaya Islam sangat kuat, yang dikenal dalam philosopi Adat Basandi Syarak Syarak Basandi Kitabullah (Padang Ekspres 14 May 2010).
Meskipun pandangan utama bapak Kosim adalah otonomi daerah, yang merupakan poin yang umum di masa ini, bapak Kosim sangat focus menekankan keunikan budaya Minangkabau yang bersumber pada Syaria dan Syaria yang bersumber pada Alquran yang kemudian memiliki potensi untuk mengembalikan pendidikan Islam karakter budaya Minangkabau.

Keputusan pemerintah daerah yang meningkatkan intensitas pendidikan agama menunjukkan penekanan pada agama di sekolahsekolah umum. In beberapa kabuapaten dan kotamadya, kesempatan untuk mendapatkan bonus ibadah haji dan umrah telah menjadi penghargaan dan hadiah bagi guru dan pendidik serta siswa. Pada tahun 2009, wakil bupati Pesisir Selatan menyebutkan: Pemerintah kabupaten Pesisir Selatan telah memiliki komitmen bahwa kepala sekolah, penilik sekolah, guru, siswa yang mencapai prestasi tertinggi akandiberikan penghargaan untuk pergi naik haji (Posmetro Padang 30 Mei 2009).

Selanjutnya pengaruh gerakan transnasional Islam kontemporer di Sumatera Barat terlihat dari pernyataan Said Agiel Siraj, Ketua Tanfizh Najdatul Ulama, dalam kunjungannnya ke Sumatera Barat tahun 2009 yang menyatakan bahwa tidak seperti di Jawa guru tarekat tidak lagi dihormati dengan baik di Sumatera Barat (Singgalang 29 July 2010). Menurut Ohruhlik (2002: 27), perendahan pandangan terhadap tarekat adalah model pemahaman keagamaan diSaudi Arabia yang mempengaruhi pandangan keagamaan di daeah Sumatera Barat. Materi pelajaran Agama di sekolah-sekolah umum di daerah ini juga mengikuti pemahaman keagamaan Saudi Arabia (Assyaukanie 2006). 
Dalam konteks pentransferan pelajaran agama yang wajib di sekolah-sekolah umum dan system pendidikan formal dan mekanisme untuk pendidikan agama, ada ekspektasi bahwa siswasiswa di Sumatera Barat diajarkan pelajaran agama untuk mengikuti agama masing-masing bukan untuk mengajak mereka ke agama baru, dan bukan juga untuk mengabaikan agama. Kurangnya kapasitas untuk mengajarkan agama kepada siswa telah menimbulkan kepanikan moral tentang kurangnya pemahaman siswa terhadap agama di daerah ini, terlihat dari popularnya perhatian terhadap kemampuan literasi siswa terhadap Alquran. Penelitian yang dipublikasikan dalam sebuah media local oleh mahasiswa IAIN Padang tahun 2004 menyebutkan 17 persen lebih dari 5000 pengantin prian dan wanita yang disurvey di kota Padang tidak bisa membaca Alquran sama sekali dan 20 persen dari mereka tidak lancer membaca Alquran. Angka lain di penelitian tersebut menunjukkan bahwa 60 persen siswa tingkatan SMP dan SMA malah tidak bisa sama sekali membaca Alquran (Singgalang 20 June 2004). Ketidak mapuan membaca Alquran ini kemudian dikaitkan dengan masalah-masalah social yang terjadi di masyarakat Sumatera Barat dan yang lebih penting lagi kurangnya keterampilan-keterampilan agama seperti membaca Alquran dikaitkan dengan persoalan moral di generasi remaja.

Dalam tema yang sama, menjadi pintar dalam pendidikan agama didemonstrasikan khusus dalam wacana public dibandingkan dengan menjadi pintar tanpa pendidikan agama. Bahkan menurut Walikota Padang tahun 2008:

Sumber daya manusia yang kita butuhkan bukan hanya yang menguasai pengetahuan dan teknologi tetapi juga sumber daya manusia yang berprilaku yang sesuai dengan ajaran agama. Kita mengingatkan semua pihak untuk menyadari bahwa pendidikan agama adalah invesmen masa depan anak yang berkualitas yang akan menjadi pemimpin Negara (Singgalang 18 December 2008).

Sebagai penjelasan tambahan terhadap apa yang dianggap pintar, seperti yang dinyatakan oleh Walikota Padang tahun 2008 di atas adalah siswa yang melakukan ibadah agama sebagai pengamalan pelajaran agama sekolah dan system pelajaran agama di sekolah akan berprilaku baik. Wacana ini membuat siswa ideal adalah siswa yang pintar dan agamis. Bahkan kunci utama dalam pernyataan wacana pendidikan agama di Sumatera Barat adalah perhatian kepada asosiasi antara pelajaran agama dan keagamaan siswa yang mengarah kepada siswa yang lebih taat kepada orang tua. Wacana inilah yang kemudian dinyatakan oleh Mahyeldi Ansharullah, walikota Padang saat ini, yang dinyatakan terkait pelaksanaan pesantren ramadhan, yang wajib diikuti semua siswa di sekolah umum selama bulan puasa tahun 2008:

Dampak positif dari pesantren ramadhan sangat jelas di kalangan siswa. Misalnya, perubahan prilaku selama bualan ramadhan dari berkeliaran tanpa tujuan kepada pergi ke mesjid. Perubahan-perubahan ini juga dirasakan oleh orang tua siswa. Karena kesempatan yang diberikan dalam pesantren ramadhan untuk bermuhasabah atau introspeksi, siswa-siswa menjadi lebih taat dan patuh kepada orang tua mereka (Padang Ekspres 30 July 2008).

Pernyataan ini mengidentifikasikan bahwa pendidikan agama dipercaya mempromosikan 
sense of industry, kesadaran pribadi dan penghormatan kepada orang lain, nilai-nilai yang dianggap sebagai antithesis dari ketidakjelasan arah dan masalah social terhadap anak-anak usia sekolah di Sumatera Barat. Bahkan menurut Fauzi Bahar, manfaat pesantren Ramadhan melebihi dari sekedar menjaga mereka berprilaku baik terhadap orang tua;

Pesantren Ramadhandi mesjid sekitar tempat tinggal siswa memiliki empat manfaat, 1) mencegah tawuran antar pelajar dan mengembangkan solidaritas antar siswa setempat 2) menghindari asmara subuh diantara siswa karena pesantren ramadhan dilaksanakan di mesjid wilayah tempat tinggal siswa 3) menghemat ongkos transportasi siswa selama bulan ramadhan karena tidak harus pergi ke sekolah 4) memberikan efek yang positif terhadap kesehatan fisik dan rohani siswa (Padang Ekspres 1 September 2009). Kecendrungan ini untuk mendorong semua jenis manfaat dari ibadah agama di Sumatera Barat adalah hal yang umum, bukan hanya dalam hubungan dengan pendidikan agama tetapi juga dalam hal prilaku dan berpakaian.

Dalam banyak pandangan komentator, pendidikan merupakan cara preventif terbaik bukan sebagai pengobat. Di akhir tahun 2008, Fauzi Bahar menjelaskan kepada harian Singgalang bahwa pemerintah kotamadya mendorong investasi di bidang pendidikan agama karena meningkatnya angka putus sekolah, penggunaan narkotika dan prilaku amoral dikalangan siswa yang disebakan oleh lemahnya pendidikan agama. Hal yang terpenting dalam pendidikan agama adalah perubahan sikap dan prilaku (Singgalang 18 December 2008). Pernyataan ini ditemukan juga dalam pandangan pimpinan daerah lain tahun 2008 seperti yang disampaikan Aristo Munandar, Bupati Agam, Pendidikan agama harus diperkenalkan sedini mungkin karena pendidikan agama mempengaruhi mental siswa dan mencegah prilaku negative termasuk penggunaan narkotika di kalangan siswa (Singgalang 30 December 2008). Hal yang sama disampaikan Ali Mukhni, wakil Walikota Padang Panjang 2008, yang mendeklarasikan bahwa salah satu cara mencegah siswa dari penggunaan narkotika adalah dengan memberikan pendidikan agama kepada anak (Singgalang 20 December 2008). Dalam contoh lain, Khatib Pahlawan Kayo, mantan pimpinan wilayah Muhammadiyah di Padang menekankan hubungan langsung antara HIV/ AIDS dan pendidikan agama. HIV dan AIDS disebabkan oleh lemahnya pendidikan agama (Singgalang 26 December 2008).

Wacana-wacana ini memanfaatkan ketakutan masyarakat akan kegagalan-kegagalan siswa dan penggunaan narkotika di kalangan pelajar untuk mendorong pendidikan agama di Sumatera Barat.

\section{Profesi dan perubahan prilaku di Sumatera Barat}

Agama selalu dianggap menjadi satusatunya solusi bagi setiap masalah prilaku oleh kalangan masyarakat beragama. Oleh karena itu, masyarakat beragama seperti masyarakat Sumatera Barat juga memahami bahwa jika semua orang memiliki agama yang baik maka masalah prilaku tidak akan muncul lagi. Asumsi ini bukanlah tidak tepat, tetapi asumsi ini masih mengabaikan factor detail lain dalam penyebab perubahan sikap. 
Bagian tulisan ini ingin menunjukkan bahwa pendidikan agama sangat penting untuk menciptakan perubahan prilaku di masyarakat tetapi perubahan prilaku masyarakat juga bisa terwujud dengan hubungan professional seseorang pekerja dengan customernya, yang dalam tulisan ini disebut dengan pelayanan pelanggan.

Pelayanan pelanggan merupakan salah satu kompenen penting yang harus dijalankan oleh semua pelaku pekerja professional yang memiliki pelanggan dan tidak mau kehilangan pelanggannya. Pelayanan pelanggan merupakan bagian kecil dari sistem manajemen profesi yang kompleks, tetapi jika dijalankan dengan baik akan memberikan manfaat yang besar untuk profesi pekerja yang bergerak dalam bidang pelayanan jasa. Pelayanan pelanggan adalah bertitik tolak pada konsep kepedulian kepada pelanggan untuk menciptakan hubungan yang baik dengan pelanggan dan memberikan kepuasan kepada pelanggan. Tindakan ini akanmembuat pelanggan bisa bertahan dan selalu datang menggunakan jasa yang diberikan sehingga profesi bisa berkelanjutan dan menguntungkan.

Pelayanan pelanggan adalah kepedulian kepada pelanggan dengan memberikan pelayanan yang terbaik untuk menfasilitasi kemudahan pemenuhan kebutuhan dengan terus mengupayakan penyelarasan kemampuan, sikap, penampilan, perhatian, tindakan dan tanggung jawab guna mewujudkan kepuasan pelanggan agar mereka selalu loyal kepada pelaku profesi tertentu. Pelayanan pelanggan adalah termasuk perbuatan atau tindakan yang memberikan kepada pelanggan sikap yang memang mereka harapkan pada saat mereka membutuhkan, dengan cara yang mereka inginkan.

Pelayanan pelanggan berasal dari konsep bahwa jasa yang ditawarkan digunakan atau dibeli oleh pelanggan. Hal ini menunjukkan bahwa pelanggan bukanlah sebuah masalah melainkan mereka adalah tujuan bisnis anda. Untuk mencapai tujuan bisnis tersebut, pelaku profesi harus memberikan perhatian dan sikap total kepada apa yang ingin pelanggan dapatkan. Tanpa pelanggan profesi pelayanan jasa tidak akan bertahan dan berkembang.

Pelayanan pelanggan sangat penting karena pelanggan bisa mencari atau menggunakan pelayanan jasa dari pelaku profesi yang lain yang mereka sukai. Mereka berhak memilih pelayanan jasa dari pelaku profesi yang memberikan pelayanan jasa terbaik. Semakin banyak pelaku profesi memberikan jasa yang kita tawarkan semakin tinggi pelayanan pelanggan yang harus kita berikan.

Pelayanan pelanggan akan menentukan sukses pelaku profesi dalam pelayan jasa. Pelanggan akan terus setia jika mereka merasa puas terhadap pelayanan jasa yang ditawarkan. Pelaku profesi pelayananjasa yang sukses adalah mereka yang bisa terus-menerus memberikan kepuasan kepada pelanggan mereka. Pelaku profesi berhasil memenangkan persaingan dan menjadi semakin besar karena bisa memberikan kualitas pelayanan yang bisa melebihi kualitas pelayanan yang diberikan oleh pesaing mereka, dan melebihi kualitas pelayanan yang diharapkan oleh pelanggan mereka.

Pelayanan pelanggan juga akanmemberi banyak keuntungan. Jika mereka puas menggunakan pelayanan jasa yang diberikan, 
mereka cenderung akan kembali untuk menggunakan pelayanan jasa yang ditawarkan. Jika mereka mendengar berita buruk mengenai jasa yang diberikan dari orang lain, mereka akan tampil memberikan testimony membela pelaku profesi yang mereka sukai. Mereka juga menjadi sarana promosi ampuh bagi pelayanan jasa yang ditawarkan. Pelanggan yang puas akan bercerita tentang kepuasan mereka menggunakan jasa yang ditawarkan pada kenalan, teman, sahabat dan sanak keluarga mereka. Ucapan mereka merupakan sarana pemasaran yang ampuh, karena mereka merupakan narasumber yang dapat dipercaya oleh orang-orang yang berhubungan dengan mereka.

Pelayanan pelanggan yang prima atau yang sering disebut Service Excellence sering menjadi materi training yang sangat penting kepada para karyawan perusahaan-perusahaan dalam mengembangkan produk dan jasa yang ditawarkan. Namun demikian, melalui observasi, tulisan ini melihat bahwa pelayanan pelanggan sudah dipahami secara bertahap oleh mereka yang berprofesi ojek di daerah Sumatera Barat.

Berdasarkan pengamatan penulis, kriminalitas lebih sering terjadi di beberapa tempat di dekat pasar di beberapa daerah observasi di Sumatera barat sebelum profesi ojek muncul secara perlahan. Para pengangguran sering berkumpul dan kemudian melakukan tindakan mengganggu masyarakat dalam bentuk pencurian dan lain-lain.

Kriminalitas yang lebih tinggi bisa terjadi dalam bentuk perkelahian dan pembunuhan. Perkelahian antar teman baik karena masalah kecil seperti ketersinggungan maupun masalah yang besar seperti masalah hutang piutang. Pembunuhan yang dipicu oleh ketersinggungan oleh suatu masalah yang kecil bisa mudah terjadi. Situasi ini membuat banyak orang khawatir dan selalu lebih waspada melewati daerah-daerah yang sering menjadi tempat berkumpul mereka ini.

Persoalan social diatas memang disebabkan oleh banyak hal mulai dari lemahnya penegakan hukum dan patroli pengawasan lingkungan oleh aparat penegak hokum, tingginya angka pengangguran dan mudahnya minuman beralkohol dikomsumsi. Namun demikian, bagian tulisan ini ingin menekankan bahwa meskipun saat ini kriminalitas masih ada dan penegakan hokum serta patroli pengawasan lingkungan oleh aparat penegak hokum masih lemah, angka pengangguran masih tinggi dan minuman beralkohol masih mudah dikomsumsi, tetapi profesi ojek, sebagai salah satu profesi pelayanan jasa, mulai merubah sikap mereka yang selama suka suka berkumpul-kumpul di daerah pasar di Sumatera Barat.

Profesi ojek membutuhkan pelanggan dan tukang ojek tidak mau kehilangan pelanggannya. Profesi ojek mengharuskan tukang ojek peduli kepada orang lain yang bisa jadi akan menjadi pelanggannya. Sikap peduli kepada orang lain ini belum muncul ketika mereka belum berprofesi sebagai tukang ojek. Kepedulian kepada orang lain atau pelanggan sangat penting untuk mempertahankan profesi tukang ojek yang dijalani sebagai sumber penghasilan seharihari dan pelanggan bisa bertahan dan selalu datang menggunakan jasa ojek yang diberikan.

Profesi ojek bukan hanya membuat tukang ojek peduli kepada orang lain tetapi juga 
terus mengupayakan sikap dan prilaku yang menyenangkan bagi orang lain. Kepedulian kepada pelanggan dengan memberikan pelayanan yang terbaik merubah sikap tukang ojek untuk terus berbenah mengasah kemampuan, penampilan, sikap, perhatian, tindakan dan tanggung jawab yang memberikan kepuasan kepada pelanggan agar mereka selalu datang dan suka menggunakan jasa ojek mereka. Profesi ojek membuat mereka melakukan tindakan yang pelanggan atau orang lain butuhkan dengan cara yang pelanggan inginkan.

Profesi ojek juga membuat tukang ojek menyadari bahwa pandangan orang lain atau pelanggan sangat penting dalam kesuksesan profesi mereka. Nasib mereka sangat tergantung kepada orang lain atau pelanggan. Perhatian dan sikap total kepada apayang diinginkan pelanggan sangat penting untuk mereka pikirkan. Mereka tukang ojek selalu memahami bahwa tanpa pelanggan profesi ojek mereka tidak akanbertahan dan berkembang.

Perhatian kepada orang lain atau pelanggan sangat penting bagi tukang ojek bukan hanya untuk mempertahankan profesi ojek di mata pelanggan tetapi juga bagi masing-masing tukang ojek. Orang yang suka dengan tukang ojek tertentu akan menjadikan tukang ojek tersebut sebagai tukang ojek langganannya. Hal ini menyebabkan tukang ojek berlomba-lomba untuk menunjukkan sikap dan pelayanan yang prima sehingga para pelanggan menjadikan mereka tukang ojek langganan dan menghubungi mereka setiap kali diperlukan. Semakin banyak seorang tukang ojek memiliki pelanggan tetap, semakin tinggi perhatian dan kepedulian tukang ojek tersebut terhadap orang lain dalam mempertahankan pelanggan tetapnya.
Tukang ojek menyadari kesuksesan mereka sangat tergantung kepuasan pelanggannya. Profesi ojek membuat mereka harus bisa terusmenerus memberikan sikap yang baik kepada orang lain. Orang lain menjadi kepanjangan tangan sukses atau tidak suksesnya mereka. Jika orang lain puas menggunakan pelayanan jasa ojek yang dia diberikan, orang lain tersebut akancenderung untuk kembali menggunakan pelayanan jasa ojek yang diberikan. Jika orang lain menyampaikan berita buruk tentang pelayanan ojek mereka, tukang ojek tersebut bisa jadi akan dihindari oleh banyak pelanggan. Orang lain bisa menjadi sarana promosi atau bencana bagi tukang ojek dari kualitas pelayanan jasa ojek yang diberikan. Pelanggan yang puas akan bercerita tentang kepuasan mereka pada kenalan, teman, sahabat dan sanak keluarga mereka. Begitu juga berita sebaliknya.

Penjelasan di atas menekankan bahwa profesi ojek mendorong tukang ojek untuk peduli kepada orang lain. Profesi ojek, sama seperti profesi penawaran jasa lainnya seperti profesi di Perbankan membutuhkan kepuasan pelanggan untuk bisa bertahan dan berkembang. Kebutuhan ini membuat pelaku profesi tersebut harus merubah sikap mereka yang bisa jadi sebelumnya egois menjadi peduli dan santun kepada orang lain. Peduli dan santun kepada orang lain adalah sikap yang penting bagi banyak profesi yang menawarkan pelayanan jasa kepada banyak orang.

\section{KESIMPULAN}

Pengambil kebijakan di bidang pendidikan dan tokoh agama sering memahami bahwa pendidikan agama secara mutlak berperan 
menjadi alat untuk merubah prilaku masyarakat. Pendidikan agama secara umum dipahami sebagai satu-satunya solusi terhadap perubahan prilaku dan mengabaikan detail lain dalam perubahan sikap masyarakat yang menurut tulisan ini bias berkaitan dengan ketersedian lapangan kerja.

Pendidikan agama merupakan solusi yang mudah untuk dilaksanakan bagi pengambil kebijakan dan mendapat dukungan yang penting dari tokoh-tokoh agama dalam merubah prilaku masyarakat ketimbang menyediakan luasnya lapangan kerja bagi banyak orang. Tulisan ini menggambarkan bahwa perubahan prilaku di masyarakat bisa dicapai dengan memperluas pekerjaan yang memberikan pelayanan jasa kepada banyak orang.

Tulisan ini merekomendasikan kepada pemerintah daerah untuk melengkapi pendidikan agama dengan meningkatkan penyediaan lapangan kerja yang luas bagi masyarakat kelas menengah ke bawah yang sering terlibat dalam prilaku maksiat. Tulisan ini juga merekomendasikan kepada berbagai pihak yang konsen dengan prilaku di masyarakat untuk menempatkan mereka yang ingin dirubah prilakunya bekerja di profesi yang membutuhkan orang lain atau pelanggan.

\section{KEPUSTAKAAN ACUAN}

Alborne, Abd Aziz. 2008. Pendidikan Agama dalam perspektif Multikulturalisme. Jakarta: PT. Saadah Cipta Mandiri.

Hefner, Robert W. 2001. The Politics of Multiculturalism: Pluralism and Citizenship in Malaysia, Singapore, and Indonesia. Hawaii: University Press.

Salim, Delmus Puneri. 2013. Islam, Politics and Identity in West Sumatra. Journal of Indonesian Islam. Vol. 07, Number 01, June 2013.

2015. Transnational and local in the politics of Islam: The Case of West Sumatra. London. Springer.

2016. Wacana Publik Keuangan Islam di Sumatera Barat. El-Hikam. Vol. I, No. 1., Januari-Juni 2016.

2016. Politics and Religious Freedom in Indonesia: The Case of West Sumatra and North Sulawesi. Journal of Government and Polititcs. Vol. 7 No. 4 November 2016. 